\title{
Plantation as Mission: American Indians, Enslaved Africans, and Jesuit Missionaries in Maryland
}

\author{
Laura E. Masur \\ Department of Anthropology, Catholic University, Washington, DC, USA \\ masur@cua.edu
}

\begin{abstract}
Jesuit endeavors in Maryland are difficult to categorize as either missions or plantations. Archaeological sites associated with the Maryland Mission/ Province bear similarities to Jesuit mission sites in New France as well as plantations in Latin America and the Caribbean. It is clear that in Maryland, the Jesuits did not enforce a distinction between missions as places of conversion and plantations as sites of capitalist production. Moreover, people of American Indian, African, and European ancestry have been connected with Maryland's Jesuit plantations throughout their history. Archaeological evidence of Indian missions in Maryland-however fragmented-contributes to a narrative of the Maryland mission that is at odds with prevailing nineteenth- and twentieth-century histories. Archaeology demonstrates the importance of critically reflecting on available historical evidence, including a historiographic focus on either mission or plantation, on the written history of Jesuits in the Americas. Furthermore, historical archaeologists must reconceptualize missions as both places and practices.
\end{abstract}

\section{Keywords}

Jesuits - English missions - plantations - slavery - religion - Maryland - Pennsylvania - American Indians - African Americans

\section{Introduction}

Between 1766 and 1769, a man named George Mingo (dates unknown) lived on the Jesuit plantation at St. Inigoes in southern Maryland; John Lewis (1721-88) kept his financial accounts. George Mingo earned £1o per year, and spent his 
earnings on tailored clothing, fabric, shoes, silk thread, and brandy. In 1768, he purchased "1 pr. of Beads," referring to a set of rosary beads used in prayer. George Mingo was also listed among enslaved Catholics "belonging to Rev. Mr. Lewis" at St. Inigoes in 1768-69. His presence in Lewis's account books is curious, as the majority of accounts belong to tenant farmers or free laborers. Only a handful of St. Inigoes accounts, dating to 1739, relate to purchases made by enslaved Africans. ${ }^{1}$ Who was George Mingo, and what was his role on the plantation? If he was enslaved, why did he earn such a significant wage? Was the name "Mingo" a marker of his ancestry or spoken language, like "Portuguese Joseph," enslaved at St. Inigoes in 1768-69? Was it an African name, or perhaps a moniker that marked his connection with Iroquoian-speaking American Indians such as Susquehannocks (sometimes called Mingos)? While the name of a particular individual may seem inconsequential, George Mingo's presence at St. Inigoes raises numerous questions about the role of people of American Indian and African descent-and indeed the challenges of applying contemporary ethnic or racial categories using documentary evidence ${ }^{2}$-in the Jesuits' Maryland Mission.

Following Ingle's Rebellion (an uprising of Protestant colonists against the Catholic governor and his allies) in 1644-46, there is an almost complete absence of documents relating to American Indian missions in Maryland. James Axtell concludes that Indian missions in Maryland ended with the rebellion, arguing that the mission accomplished little in its truncated eleven-year history. ${ }^{3}$ Few historians have questioned this narrative, and histories of the later seventeenth- and eighteenth-century Maryland mission

1 St. Inigo's Rents, 16 November 1767-20 July 1769, Box 43, Folder 2, Maryland Province Archives of the Society of Jesus (MPA), Georgetown University Archives, Washington, DC. The name "Mingo George" is used in the St. Inigo's rent books, whereas "George Mingo" was referenced in church records. Edwin Warfield Beitzell, The Jesuit Missions of St. Mary's County, Maryland (Abell, MD: St. Mary's County Bicentennial Commission, 1959), 76. Sam, Ben, and Jenny St. Inigo purchased fabrics from the Jesuits. St. Inigo's Rents, 1739, Box 43, Folder 2, MPA.

2 See Julia A. King and Edward E. Chaney, "Passing for Black in Seventeenth-Century Maryland," in Interpreting the Early Modern World, ed. Mary C. Beaudry and James Symonds (New York: Springer, 2011), 87-112.

3 James Axtell, "White Legend: The Jesuit Missions in Maryland," Maryland Historical Magazine 81 (Spring 1986): 1-7. See also James H. Merrell, "Cultural Continuity among the Piscataway Indians of Colonial Maryland," The William and Mary Quarterly 36, no. 4 (1979): 548-70, doi:10.2307/1925183; Kathleen Elizabeth Scorza, "False Emissaries: The Jesuits Among the Piscataways in Early Colonial Maryland, 1634-1648" (MA thesis, The College of William and Mary, 2015). While Scorza's treatment of the Jesuit-Piscataway relationship is more detailed and nuanced, her discussion of the mission nonetheless ends in 1648. 
are almost exclusively focused on ministry to Euro-American colonists, with increasing acknowledgement of African American slavery. ${ }^{4}$ As a result, recent narratives of the English Jesuits in Maryland are framed largely in terms of plantation slavery. ${ }^{5}$ In contrast, research on the Jesuit presence in New France focuses almost exclusively on Indian missions and frontier forts, despite the Jesuits' role as the largest seigneurial landholders along the Saint Lawrence River. Likewise, historian Nicholas Cushner thematically separates his treatment of Indigenous missions in North and South America from his extensive research on the Jesuits' plantation systems. ${ }^{6}$ Moreover, the study of missions and plantations form divergent literatures within historical archaeology in the Americas. ${ }^{7}$ Either a site is a religious mission, focused on the conversion of American Indians, or a plantation, tied to the economic exploitation of enslaved Indian or African labor to earn a profit.

Historical archaeologists must reconceptualize missions as both places and practices. Here, I use archaeological evidence to illustrate how a mobile,

4 E.g., William P. Treacy, Old Catholic Maryland and Its Early Jesuit Missionaries (Swedesboro, NJ: St. Joseph's Rectory, 1889), http://archive.org/details/oldcatholicmarylootrea (accessed January 14, 2021); Robert Emmett Curran, “Splendid Poverty': Jesuit Slaveholding in Maryland, 1805-1838," in Catholics in the Old South: Essays on Church and Culture, ed. Randall M. Miller and Jon L. Wakelyn (Macon, GA: Mercer University Press, 1983), 125-46; Thomas Murphy, Jesuit Slaveholding in Maryland, 1717-1838 (New York: Routledge, 2001); Adam Rothman, "Georgetown University and the Business of Slavery," Washington History 29, no. 2 (2017): 18-22. The widespread phenomenon of Jesuit slaveholding and plantations remains a difficult and often embarrassing topic for contemporary Jesuit scholars. See Murphy, Jesuit Slaveholding, xii-xxiii. See also Adam Rothman "The Jesuits and Slavery," Journal of Jesuit Studies 8, no. 1 (2021): 1-10, doi:10.1163/22141332-0801Poo1.

5 The framing of historical research on the Maryland Jesuits follows the format of Nicholas Cushner's and Herman Konrad's studies of Spanish Jesuit estates in Central and South America, as well as French Jesuits in Louisiana and the Caribbean and Portuguese Jesuits in Brazil, e.g., Nicholas P. Cushner, Lords of the Land: Sugar, Wine, and Jesuit Estates of Coastal Peru, 1600-1767 (Albany: State University of New York Press, 1980); Herman W. Konrad, $A$ Jesuit Hacienda in Colonial México: Santa Lucía, 1576-1767 (Stanford, CA: Stanford University Press, 1980); Andrew Dial, "The 'Lavalette Affair': Jesuits and Money in the French Atlantic" (unpublished PhD diss., McGill University, 2018); Adam Rothman, "The Jesuits and Slavery," Journal of Jesuit Studies 8, no. 1 (2021): 1-10, doi: 10.1163/22141332-0801Poo1.

6 Allan Greer, The Jesuit Relations: Natives and Missionaries in Seventeenth-Century North America (Boston, MA: Bedford/St. Martin's, 200o); Cole Harris, The Seigneurial System in Early Canada: A Geographical Study (Madison, WI: University of Wisconsin Press, 1966); Nicholas P. Cushner, Why Have You Come Here?: The Jesuits and the First Evangelization of Native America (Oxford: Oxford University Press, 2006).

7 For example, Lee M. Panich, "Mission Archaeology in North America," in Encyclopedia of Global Archaeology, 2nd ed., ed. Claire Smith (New York: Springer-Verlag, 2018), doi:10.1007/978-3-319-51726-1_1396-2; James A. Delle, "Plantation Archaeology," in Encyclopedia of Global Archaeology (New York: Springer, 2014), 5978-85. 
practice-centered concept of "mission" pervaded religious and economic relationships among American Indians, enslaved Africans, Euro-American colonists, and Jesuits in Maryland. ${ }^{8}$ Because of the Jesuits' fraught relationship with England as a colonial power and with the proprietary governments of Maryland and Pennsylvania, documentary evidence is inconsistent, largely comprising letters and land transactions. The earliest surviving sacramental records date to 1741 , and personal letters were frequently written in opaque codes. Moreover, only portions of the Litterae annuae (yearly letters) have been transcribed or translated, with most research completed during the nineteenth or early twentieth centuries. ${ }^{9}$ As a result, historians have framed Jesuit endeavors in the Middle Atlantic region primarily as missions to Euro-American colonists, plantations, and colleges. Yet archaeological sites associated with the Maryland Mission, and after 1833 the Maryland Province, bear similarities to Jesuit mission sites in New France as well as plantations in Latin America and the Caribbean. In Maryland, Jesuits ran plantations that also functioned as missions, while also conducting missions in American Indian communities, blurring lines that are analytically distinct in the historical and archaeological literature. It is clear that in Maryland, the Jesuits did not enforce a distinction between missions as places of evangelization and plantations as sites of capitalist production. Far from one being "religious" and the other "economic," missions and plantations bear characteristics of religious goals and their

8 I use the term "Maryland" to refer to the territory of the Maryland mission, which in the seventeenth and eighteenth centuries also included Pennsylvania, Delaware, New Jersey, and New York.

9 Elizabeth Petty Bentley, ed., The Goshenhoppen Registers, 1741-1819: Registers of Baptisms, Marriages and Deaths of the Catholic Mission at Goshenhoppen (Bally), Washington Township, Berks County, Pennsylvania (Baltimore, MD: Genealogical Pub. Co., 1984). For example, 1710 letters sent from Maryland to superiors in England use the term "factory" to refer to the mission, and "customers" to refer to congregants. Thomas Hughes, History of the Society of Jesus in North America: Colonial and Federal, vol. 2: From 1645 till 1773 (London: Longmans, Green, and Co., 1917), 436-37, https://archive.org/details/historyofsocieto2hugh (accessed January 14, 2021). Partial transcriptions and translations of the Litterae annuae from Maryland appear in the compilations of Henry Foley, Thomas Hughes, and the Woodstock Letters, e.g., Henry Foley, Records of the English Province of the Society of Jesus: Historic Facts Illustrative of the Labours and Sufferings of Its Members in the Sixteenth and Seventeenth Centuries, 3 vols. (London: Burns and Oates, 1878), http://archive.org/details/ recordsofenglishoofole (accessed January 14, 2021). Thomas Hughes, History of the Society of Jesus in North America: Colonial and Federal, Documents, vol. 1 part 1, nos. 1-140 (1605-1838) (London: The Burrows Brothers Company, Longmans, Green, and Co., 1908), http://archive. org/details/historyofsociety1717hugh (accessed January 14, 2021). "Papers relating to the Early History of the Maryland Mission, V: The Annual Letters, 1634-1773," Woodstock Letters 10, no. 3 (1881): 209-24. 
means of economic support. Most notably, American Indians remained associated with Jesuit plantations in ways that are challenging to interpret with sparse historical documentation. Archaeology provides hints, if not concrete evidence, of the entwined relationships between missions and plantations in Maryland. Nonetheless, English Jesuit connections with Iroquoian-speaking Susquehannocks, and economic dependence on African slavery, suggests that both interpretations of George Mingo — as an American Indian or an African American-are plausible.

\section{Mission as Place or Practice?}

Christian missions were, and are, a global phenomenon. Historical and archaeological literature on North American missions highlights their role in European transatlantic expansion and Indigenous culture change during the sixteenth through nineteenth centuries, but missionary efforts were both diverse and widespread. While most archaeological research has focused on Jesuit missions in New France and Spanish Franciscan missions in Florida, California, and the American Southwest, both Protestants and Catholics from diverse European nations operated missions in colonial North America. The archaeological study of Spanish and French missions emphasizes interactions among European missionaries, colonists, and Indigenous neophytes, examining continuity and change in material culture, diet, and health as well as religious practice. Spanish and French missions, although administered by several religious orders, maintained close relationships between church and state, as well as military and economic ventures. ${ }^{10}$

10 Ronnie Po-chia Hsia, "Jesuit Foreign Missions: A Historiographical Essay," Journal of Jesuit Studies 1, no. 1 (2014): 47-65, doi:10.1163/22141332-0o101004; Elizabeth Graham, "Mission Archaeology," Annual Review of Anthropology 27 (1998): 25-62; Bonnie G. McEwan, The Spanish Missions of La Florida (Gainesville: University Press of Florida, 1993); Kent G. Lightfoot, Indians, Missionaries and Merchants: The Legacy of Colonial Encounters on the California Frontiers (Berkeley: University of California Press, 2004); Christopher M. Stojanowski, Mission Cemeteries, Mission Peoples: Historical and Evolutionary Dimensions of Intracemetery Bioarchaeology in Spanish Florida (Gainesville: University Press of Florida, 2013); Lee M. Panich and Tsim D. Schneider, "Expanding Mission Archaeology: A Landscape Approach to Indigenous Autonomy in Colonial California," Journal of Anthropological Archaeology 40 (2015): 48-58; José António Brandão and Michael S. Nassaney, "Suffering for Jesus: Penitential Practices at Fort St. Joseph (Niles, Michigan) During the French Regime," The Catholic Historical Review 94, no. 3 (2008): 476-99; Stephan T. Lenik and Brenda Hornsby Heindl, "Missionaries, Artisans, and Transatlantic Exchange: Production and Distribution 
Most North American archaeologists consider missions to be places of sustained cultural contact between missionaries and American Indians as part of colonial regimes. Throughout the Americas, local environments, economic pursuits, and colonial politics played an important role in the structure and history of mission settlements. Spanish Franciscans usually designed mission towns, with a regular plan that included a church, a residence for missionaries (convento or friary), a residence for Indigenous neophytes, and places that were open to non-Christians. Franciscans also established these settlements within Native villages; in some cases, such as Awatovi in Arizona and Lamanai in Belize, mission churches were built on top of Indigenous religious structures.11 The influence of Spanish mission archaeology is evident in the ways that archaeologists, in particular, characterize missions. Archaeologist David Snow defines a mission as a bounded space administered by a religious organization, where economic and domestic activities take place. ${ }^{12}$ Specifically tailored to Spanish agro-pastoral mission systems, this definition is site-oriented and focuses on economic rather than evangelical goals. Indeed, archaeologist Elizabeth Graham's seminal assessment of mission archaeology exclusively references Spanish missions in North America. Although Graham acknowledges the limiting factors of a place-centered definition, the archaeological conception of missionas-place-and as a largely Spanish /Indigenous phenomenon-persists today. ${ }^{13}$

As shown in the research of José António Brandão and Michael Nassaney, and Andrew Beaupré (this issue), Jesuit missions to Indigenous people in North America were characterized by mobility and flexibility, in order to more effectively secure conversions. Contemporary scholarship acknowledges the complicated religious, cultural, and moral situations faced by members of the Society of Jesus and the people they sought to convert. Researchers highlight the concept of accommodation, adaptations or compromises made by

of Moravian Pottery in Pennsylvania and the Danish (U.S.) Virgin Islands," Historical Archaeology 48, no. 4 (2014): 95-117.

11 Graham, "Mission Archaeology," 38, 50.

12 David H. Snow, "Archaeology and 19th-Century Missions," Historical Archaeology 1 (1967): 57-59, here 59 .

13 Graham, "Mission Archaeology," 26; Panich, "Mission Archaeology"; Mark T. Lycett, "Archaeology under the Bell: The Mission as Situated History in Seventeenth-Century New Mexico," Missionalia 32, no. 3 (2004): 357-79, here 358. While Lycett acknowledges the function of missions "simultaneously as place, as emergent community, and as an institutional logic or colonial project," he focuses specifically on the role of placemaking at the seventeenth-century Franciscan mission San Pedro in New Mexico. 
members of the Society in order to ensure the success of their mission. Jesuit accommodation took the form of learning Native languages, adapting to local cultural traditions, and finding common ground with prospective converts. ${ }^{14}$ So too did the principle of accommodation influence a Jesuit approach to the spatial layout of missions. Throughout the Americas, Spanish and Portuguese Jesuits established reducciones, consolidated mission towns of Indigenous people from surrounding areas, in order to facilitate conversion and agricultural production. In New France, Jesuits constructed core missions, such as Sainte Marie in Ontario, that bore physical similarities to the regimented Franciscan layout. However, they also migrated between permanent mission sites, American Indian villages, and French forts, such as Fort St. Joseph in Michigan. Roman Catholic portable material culture-particularly crosses/ crucifixes and religious medallions - rather than architecture is particularly important for identifying ephemeral mission sites in New France. ${ }^{15}$

An archaeological definition of mission-as-place is difficult to reconcile with the flexibility and mobility engendered by Jesuit accommodation. A broader interpretation of mission, summarized by historian Brian Stanley, focuses instead on the ecclesiastical promulgation of Christian beliefs and moral values. The term "mission," originating in the sixteenth century with Ignatius of Loyola (c.1491-1556), was based on the idea that Christians would spread their faith among nonbelievers. ${ }^{16}$ Considering missions as practices rather than places expands the archaeological study of missions in two ways. First, it permits a mobile or multi-sited perspective on missions as part of an interconnected network of people, practices, and places. Second, it enables researchers to study the role of missionary activity in social or economic

14 Emanuele Colombo, "Infidels' at Home," Journal of Jesuit Studies 1, no. 2 (2014): 192-211, doi:10.1163/22141332-001020o3; Hsia, "Jesuit Foreign Missions," 52-56; Ananya Chakravarti, The Empire of Apostles: Religion, Accommodation and The Imagination of Empire in Modern Brazil and India (Oxford: Oxford University Press, 2018); Andrés I. Prieto, "The Perils of Accommodation: Jesuit Missionary Strategies in the Early Modern World," Journal of Jesuit Studies 4, no. 3 (2017): 395-414, doi:10.1163/22141332-00403002.

15 Clement James McNaspy, "The Archaeology of the Paraguay Reductions (16o9-1767)," World Archaeology 18, no. 3 (1987): 398-410; Wilfrid Jury and Elsie McLeod Murray Jury, Sainte-Marie among the Hurons (Toronto: Oxford University Press, 1954); Kenneth E. Kidd, The Excavation of Sainte-Marie I, reprint ed. (University of Toronto Press, 1974); Daniel K. Richter, "Iroquois versus Iroquois: Jesuit Missions and Christianity in Village Politics, 1642-1686," Ethnohistory 32, no. 1 (1985): 1-16; Andrew R. Beaupré, "Sacred or Secular: Religious Materiality on the French Colonial Frontier" (MA thesis, Western Michigan University, 2011).

16 Brian Stanley, "Mission: Proselytization and Conversion," in International Encyclopedia of the Social \& Behavioral Sciences (Second Edition), ed. James D. Wright (Oxford: Elsevier, 2015), 614-17, here 614 . 
aspects of everyday life, rather than solely in religious belief or ritual. ${ }^{17} \mathrm{I}$ argue that historical archaeologists must reconceptualize missions-especially Jesuit missions-in order to align them with the comparative, international scope of contemporary historical and archaeological research.

Considering evangelization efforts among diverse groups of people, ranging from the faithful to the cultural or religious Other, moreover, requires a concept of mission that is applicable in globally variable contexts. For example, Jesuits in seventeenth-century Spain and Naples sought to convert Muslim slaves from Northern Africa as an alternative to foreign missions. English Jesuit missionaries were also active in Elizabethan England during the late sixteenth century, following the establishment of the Church of England. Jesuits in Maryland focused missionary efforts on Catholic populations, also seeking to evangelize American Indians, enslaved Africans, and European Protestants. ${ }^{18}$ Here, I define a Christian mission as a suite of social, economic, and religious practices that occurs within a circuit of places, administered by a larger church or religious order based on belief in the universality of Christian faith. I suggest that missions encompass a variety of places and practices, but are distinct from other institutions because of their central administration and evangelical ideals. This definition also allows researchers to conceptualize traditionally "secular" landscapes as part of the "mission field."19

Archaeological research on missions must, furthermore, consider another "type" of site: the plantation. Studied within a separate body of archaeological literature, research on plantations focuses on the material lives of enslaved Africans and how enslavers maintained power structures through architecture and landscape design. Literature in African diaspora archaeology is theoretically informed, collaborative, and politically active, seeking

17 George E. Marcus, "Ethnography in/ of the World System: The Emergence of Multi-Sited Ethnography," Annual Review of Anthropology 24, no. 1 (1995): 95-117; Krysta Ryzewski, "Multiply Situated Strategies?: Multi-Sited Ethnography and Archeology," Journal of Archaeological Method and Theory 19, no. 2 (2011): 241-68; Mary C. Beaudry and Travis G. Parno, eds., Archaeologies of Mobility and Movement (New York: Springer, 2013); Stephen W. Silliman, "Theoretical Perspectives on Labor and Colonialism: Reconsidering the California Missions," Journal of Anthropological Archaeology 20, no. 4 (2001): 379-407.

18 Emanuele Colombo, "Infidels' at Home"; Robert E. Scully, Into the Lion's Den: The Jesuit Mission in Elizabethan England and Wales, 1580-1603 (St. Louis, MO: Institute of Jesuit Sources, 2011); Cushner, Why Have You Come Here?; Leo Gregory Fink, Old Jesuit Trails in Penn's Forest: The Romance of Catholicity Told in the Footprints of the Pioneer Missionaries of Eastern Pennsylvania (New York: Paulist Press, 1933), http://babel.hathitrust.org/cgi/ pt?id=wu.89077000859 (accessed January 14, 2021). Axtell, "White Legend"; Murphy, Jesuit Slaveholding in Maryland.

19 For a discussion of these terms, see Stanley, "Mission," 615. 
to raise consciousness about issues of race, class, and labor in early modern capitalist societies and today. ${ }^{20}$ Numerous historians have written about missionaries' efforts to convert and minister to people of African descent, despite the seemingly contradictory relationship between religious conversion and bodily enslavement in twenty-first-century thought. These efforts were widespread, from the conversion of free blacks at Fort Mosé in Spanish Florida, to the conversion of enslaved Africans on plantations throughout the Americas. Although missionaries originally exploited Indigenous labor, enslaved African labor became common following Indigenous demographic collapse. As enslaved African labor began to replace Indigenous labor during the sixteenth and seventeenth centuries, landowning missionaries frequently switched their evangelical focus to enslaved Africans. In tropical areas such as Latin America and the Caribbean, Spanish, Portuguese, and French Jesuits established large agricultural settlements, commonly characterized as plantations or haciendas for their scale and economic focus on cash crops. ${ }^{21}$

Nonetheless, it is less common to characterize missionary activities-administered by Jesuits or by other religious groups-directed at people of African descent as missions, especially in American archaeological literature, because of the close conceptual association between missions and American Indians. In an effort to complicate this trend, archaeologist Steve Lenik uses the term "mission plantation" to distinguish Jesuit plantations in the French Caribbean from estates owned by non-religious landowners. Archaeologist Brendan Weaver describes the way that Jesuit plantation administrators encouraged Christian discipline among enslaved laborers in order to achieve

20 Theresa A. Singleton, "African Diaspora Archaeology in Dialogue," in Afro-Atlantic Dialogues: Anthropology in the Diaspora, ed. Kevin A. Yelvington (Santa Fe, NM: School for Advanced Research, 2006), 249-87; Maria Franklin and Larry McKee, "Introduction to African Diaspora Archaeologies: Present Insights and Expanding Discourses," Historical Archaeology 38, no. 1 (2004): 1-9; Christopher C. Fennell, "Introduction: Navigating Intersections in African Diaspora Archaeology," Historical Archaeology 51, no. 1 (2017): 1-8; Mark P. Leone, "Interpreting Ideology in Historical Archaeology: Using the Rules of Perspective in the William Paca Garden in Annapolis, Maryland," in Ideology, Power, and Prehistory, ed. Daniel Miller and Christopher Tilley (Cambridge: Cambridge University Press, 1984), 25-35.

Jane Landers, "Gracia Real de Santa Teresa de Mose: A Free Black Town in Spanish Colonial Florida," The American Historical Review 95, no. 1 (1990): 9-30; Alida C. Metcalf, Go-Betweens and the Colonization of Brazil, 1500-160o (Austin: University of Texas Press, 2005), 158; Joan Meznar, "Our Lady of the Rosary, African Slaves, and the Struggle against Heretics in Brazil, 1550-166o," Journal of Early Modern History 9, no. 3 (2005): 371-97; James A. Delle, "Race, Missionaries, and the Struggle to Free Jamaica," in Race and the Archaeology of Identity, ed. Charles E. Orser, Jr. (Salt Lake City: University of Utah Press, 2001), 177-95; Murphy, Jesuit Slaveholding in Maryland; Hsia, "Jesuit Foreign Missions." 
their dual goals of economic advantage and evangelization. ${ }^{22}$ Evidence from Maryland shows the evolution of Jesuits' goals for their mission, from a focus on American Indians and English Protestants in the seventeenth century, to enslaved Africans and tenant farmers, and ultimately to European immigrants in nineteenth-century cities. These evangelical goals were closely connected with changes in the mission's economic foundations. Archaeological and historical evidence is a testament to the variety of places and practices encompassed by this mission.

\section{Jesuit Missions and Plantations in Maryland}

In the early seventeenth century, land north of the Potomac River was the domain of the Piscataway confederacy, governed by a paramount leader known as the Tayac. Numbering several thousand persons living in villages along the Potomac River, ${ }^{23}$ Piscataways faced conflicts from the encroaching Susquehannocks. The foundation of the Maryland colony provided the Tayac with new opportunities for alliance with the English. ${ }^{24}$ Invited by Cecil Calvert $\left(1605^{-75}\right)$ to serve as priests for the fledgling colony, Jesuits nonetheless had a variety of motivations when volunteering for the Maryland mission. The desire to work specifically with English "heretiques" and Indigenous "barbarians" was chief among them, as was a yearning for martyrdom. ${ }^{25}$ The first decades in Maryland were tumultuous: although the Jesuits achieved some early successes among the Piscataways, they were also forced to contend with anti-Catholic sentiments from within the colony. After deposing his brother Wannas (d.1634), the new Tayac Kittamaquund (d.1641) invited the Jesuit

22 Stephan T. Lenik, "Mission Plantations, Space, and Social Control: Jesuits as Planters in French Caribbean Colonies and Frontiers," Journal of Social Archaeology 12, no. 1 (2012): 51-71; Brendan J. M. Weaver, "Rethinking the Political Economy of Slavery: The Hacienda Aesthetic at the Jesuit Vineyards of Nasca, Peru," Post-Medieval Archaeology 52, no. 1 (2018): 117-33. See also Weaver, "The Grace of God and Virtue of Obedience" (this issue).

23 Population estimates for the Piscataways in the early seventeenth century, based on historical and bioarchaeological evidence, vary between 1,000 and over 7,000. Ethnohistorian Paul Cissna estimates a population of about 3,6oo, spread across a number of village sites. There is little evidence for epidemics or significant demographic decline following Maryland's foundation; most sources point to early seventeenth-century epidemics. Paul Byron Cissna, "The Piscataway Indians of Southern Maryland: An Ethnohistory from Pre-European Contact to the Present" (unpublished PhD diss., American University, 1986), 49-6o, 106-9.

24 Merrell, "Cultural Continuity"; Scorza, "False Emissaries."

25 Anon., "Applications for the Maryland Mission, 1640," Woodstock Letters 9, no. 2 (1880): $73-94$. 
Andrew White (1579-1656) to live with him at Piscataway. When White aided his recovery from a serious illness, Kittamaquund and his family welcomed instruction in Catholicism and converted in 1640-an act often attributed to political rather than religious motivations. ${ }^{26}$

The Jesuits were soon forced to temporarily flee Maryland during two Puritan military uprisings in 1645 and 1655 . Several of these missionaries died in Virginia in subsequent years, and the others struggled to regain the Society's foothold in Maryland. By 1697, when Maryland governor Francis Nicholson (in office 1694-98) requested a census of Roman Catholic clergy, three Jesuit priests, an ex-Jesuit, a Franciscan, and two Jesuit brothers resided in the two southernmost counties: St. Mary's and Charles. Based on the documented location of three plantations and nine chapels, it appears that the majority of their public ministry focused on these two counties, as well as a small presence on Maryland's Eastern Shore. ${ }^{27}$ The passage of "An Act to Prevent the Growth of Popery" in 1704 restricted the public practice of Catholicism in Maryland, closing many of these chapels and shifting to worship in private homes.

Despite these obstacles, the number of Jesuit mission outposts in Maryland grew during the eighteenth century. Plantations-owned by Jesuits and other elite Marylanders - were increasingly central to the practice of Roman Catholicism. ${ }^{28}$ Following the passage of the 1704 Act, the Jesuits acquired additional plantations in Cecil, Prince George's/ Anne Arundel, Harford, Talbot, and possibly Frederick/ Carroll Counties (Figure 1). Archaeology and architectural history are vital to reconstructing the history of the seven known Jesuit plantations in Maryland. The earliest structures still standing today were built in the 1740s, a historical moment from which some mundane records like ledgers and tenancy documents are also preserved. Nonetheless, archaeology provides the most detailed evidence of seventeenth-century occupation and plantation expansion at St. Inigoes and Newtown, both in St. Mary's County. ${ }^{29}$ Communities surrounding plantation churches grew at least in part because

26 Both Merrell, "Cultural Continuity," and Scorza, "False Emissaries," interpret Kittamaquund's conversion as a political act made in order to form an alliance with the English.

27 Hughes, History of the Society of Jesus in North America, 2:450-51.

28 Tricia T. Pyne, "Ritual and Practice in the Maryland Catholic Community, 1634-1776," U.S. Catholic Historian 26, no. 2 (2008): 17-46.

29 Laura E. Masur, "Priestly Plantations: An Archaeology of Capitalism and Community in British North America" (unpublished PhD diss., Boston University, 2019), 130-89. Archaeology is also central to understanding the role of Jesuits in Maryland's original capital, St. Mary's City. See Timothy B. Riordan, Henry M. Miller, and Silas D. Hurry, "Birth of an American Freedom, Religion in Early Maryland: Archaeology of the St. Mary's City Chapel Field (18ST1-103)," Report submitted to National Endowment for the Humanities Grants Office, Washington, DC (St. Mary's City, MD: Historic St. Mary's City, 1994). 

1. St. Inigoes 1637-1919
2. St. Thomas 1649-Present
3. Newtown 1668-1868
4. Bohemia 1704-1898
5. White Marsh 1728-1903
6. Conewago 1742-1901
7. Goshenhoppen $1747-1889$
8. Deer Creek 1750-1814
9. St. Joseph $1765-1864$
10. Coffee Run 1772-1810
11. Paradise $1820-1891$
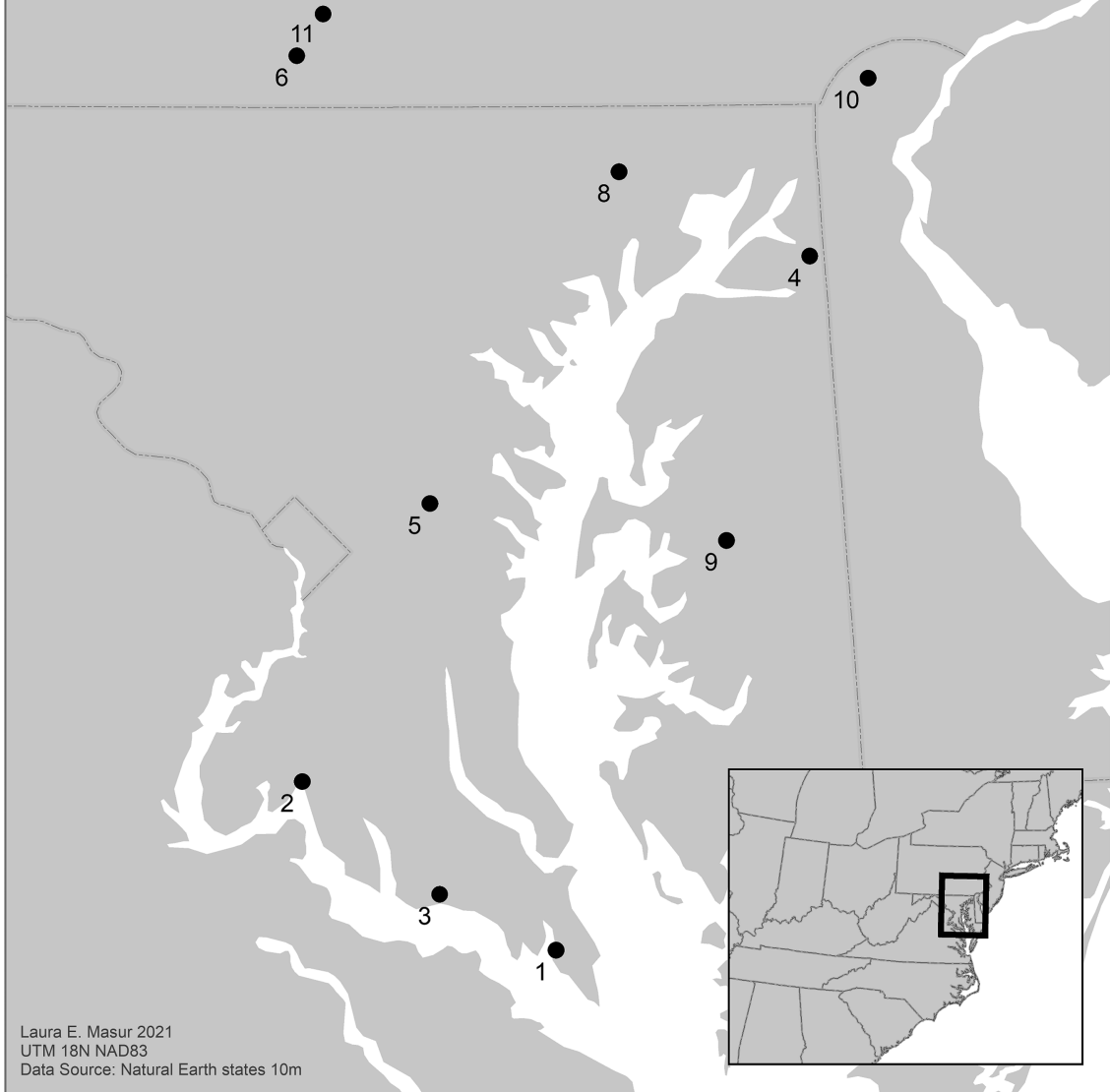

FIGURE 1 Jesuit residential estates in the Middle Atlantic region; dates specify Jesuit residence

IMAGE COURTESY OF AUTHOR

of Jesuits' active efforts to convert Protestants. In 1674, French Jesuit Jean Pierron (b.1631) observed, following a visit to St. Thomas Manor, that English Jesuits in Maryland focused primarily on "the reduction of the heretics of the country." Protestant ministers complained of "Romish pamphlets" distributed 
throughout St. Mary's County in 1734, and of Jesuits "preaching publicly to large mixed Congregations in Port Tobacco Court House" at some point before $1753 \cdot{ }^{30}$

Tracing the path of American Indian missions - and moreover any interactions with American Indians after Ingle's Rebellion-is far more difficult than documenting the conversion of Protestants. While in exile in Virginia in 1655, Lawrence Starkey (1606-57) requested that the superior general send younger men to America, who could learn "the language of the country," providing evidence for continued missionary work with American Indians. Moreover, Bishop François de Laval (1623-1708) of Quebec referred in 1663 to an Indian mission along the Delaware River in New Sweden, which was run by English Jesuits from Maryland. Official references and local suspicions about Indian missions continue into the eighteenth century, when some Piscataways migrated north into Pennsylvania. Like the Susquehannocks (or Conestogas), Piscataways (or Conoys) settled in towns along the Susquehanna River. ${ }^{31}$ The Jesuit catalogs place Thomas Diggs (1711-1805) "in Sesquahanock" in 1749, and "in Sequanock" in $175^{\circ}$ and 1752, implying residence in a Susquehannock or other Native village along the Susquehanna River. Furthermore, Theodore Schneider (1703-64), a German Jesuit assigned to Maryland, allowed several Native American families to live on his recently purchased plantation at Goshenhoppen (Berks County, Pennsylvania) in 1755 . These references provide consistent, albeit vague, support for missions to Indian nations, established by the Maryland mission. ${ }^{32}$

Surveying portable material culture through archaeology provides an additional means of examining the geography of cultural and religious

30 Reuben Gold Thwaites, ed., The Jesuit Relations and Allied Documents: Travels and Explorations of the Jesuit Missionaries in New France, 1610-1791, 73 vols. (Cleveland: The Burrow Brothers, 1896-1901), 59:75. Hughes, History of the Society of Jesus in North America, 2:513. Beatriz Betancourt Hardy, "Papists in a Protestant Age: The Catholic Gentry and Community in Colonial Maryland, 1689-1776" (unpublished PhD diss., University of Maryland, 1993), 548.

31 Cissna, "The Piscataway Indians," 191-202; Barry C. Kent, Susquehanna's Indians (Harrisburg: The Pennsylvania Historical and Museum Commission, 1984), 70-78; James D. Rice, Nature and History in the Potomac Country: From Hunter-Gatherers to the Age of Jefferson (Baltimore, MD: Johns Hopkins University Press, 2009), 161-73.

32 The catalogs contain biographical information on Jesuits for each province, including their residence and assigned mission. Hughes, History of the Society of Jesus in North America, 2:59, 65, 691-92. Anna Dill Gamble, "An Ancient Mission Among a Great People," Records of the American Catholic Historical Society of Philadelphia 6o, no. 3 (1949): 125-43, 141-44; "Father Richard Molyneux, S.J. Assists the Pennsylvanians in Making a Treaty with the Indians, 1744," The American Catholic Historical Researches 9, no. 1 (1892): 42; Helen A. Heinz, "We are all as one fish in the sea...: Catholicism in Protestant Pennsylvania: 1730-179o" (unpublished PhD diss., Temple University, 2008), 159. 
interchanges between Jesuits and American Indians in Maryland. In New France, archaeologists have found a strong correlation between the presence of Roman Catholic devotional objects at Indigenous sites and the location of historically documented Jesuit missions. ${ }^{33}$ This method of using the presence of devotional artifacts from archaeological sites to infer connections to the Jesuits - applied to Maryland's poorly documented Indian missions - can be used to detect the reach of missionary activity. The original 1634-45 Indian mission sites in Maryland have not been identified archaeologically. Nonetheless, devotional artifacts such as crosses, medals, and "Jesuit" rings have been found at Indigenous sites across Virginia, Maryland, Pennsylvania, and New Jersey. Identified at sites occupied by Piscataways, Susquehannocks, Delawares, Rappahannocks, and Patawomecks, these objects provide clues to interaction-direct or indirect — with Maryland Jesuits. The most abundant archaeological evidence comes from seventeenth- and eighteenth-century Piscataway sites. For example, a fragment of a lead cross was excavated from a likely Piscataway site in Zekiah Swamp (Windy Knolls I, 18CH8o8) in Maryland. A ring, bearing an image of the crucifixion, was excavated from the eighteenth-century Piscataway occupation at Heater's Island $\left(18 \mathrm{FR}_{72}\right)$ in the Potomac River. Numerous crucifixes, medals, and rosary-like necklaces were excavated from the eighteenth-century Piscataway burial ground at Conoy Town (36LA40, 36LA57), along the Susquehanna River in Pennsylvania. Graves in a Susquehannock cemetery known as Conestoga Town (36LA52), located several miles downriver, also contain numerous crosses, crucifixes, medals, and at least one modified rosary. Digges' Susquehannock/Susquehanna mission most likely included Conestoga and Conoy, possibly among other American Indian villages clustered along the Susquehanna River in the mid-eighteenth century. These sites mark not only the continued migration of Piscataways and other American Indian communities across Maryland and Pennsylvania, but also indicate at least a century of punctuated interaction with Jesuit missionaries. ${ }^{34}$

33 Charles J. Rinehart, Crucifixes and Medallions: Their Role at Fort Michilimackinac, Volumes in Historical Archaeology, 11 (Columbia: The South Carolina Institute of Archaeology and Anthropology, The University of South Carolina, 1990); Beaupré, "Sacred or Secular."

34 Alex J. Flick, Skylar A. Bauer, Scott M. Strickland, D. Brad Hatch, and Julia A. King, “...A place now known unto them': The Search for Zekiah Fort" (St. Mary's City, MD: St. Mary's College of Maryland, 2012), 156-57; Sara Rivers Cofield, "Religious Artifacts," Diagnostic Artifacts in Maryland, May 14, 2014, https://apps.jefpat.maryland.gov/diagnostic/ SmallFinds/ReligiousArtifacts/index-religiousartifacts.htm (accessed January 14, 2021); Kent, Susquehanna's Indians, 285-86. For an evaluation of historical and archaeological evidence related to American Indian missions in Maryland, Pennsylvania, and New York, and how objects may have been interpreted through Indigenous cosmology, see Masur, 
Reversing this pattern of exchange-searching for the presence of Indigenous artifacts at Jesuit plantations - can also be used to clarify these poorly documented relationships. Trade was central to initial Jesuit-Piscataway interactions, providing financial support for the mission and an opportunity to build relationships with prospective converts. Jesuits provided manufactured goods such as hatchets, axes, hoes, knives and cloth, in exchange for beaver skins. Indeed, Kathleen Scorza argues that Piscataways eagerly forged connections with the Jesuits as emissaries of the Maryland colony, which they hoped would serve as a buffer in conflict with the Susquehannocks. ${ }^{35}$ Archaeological evidence suggests that Jesuits also received locally produced terra cotta tobacco pipes from American Indians (Figure 2). These pipes, found primarily at seventeenth-century sites in the Chesapeake region, often bear American Indian designs and are generally attributed to creolized American Indian pipe-makers. Terra-cotta pipes comprise sixty-five percent of all tobacco pipes from the seventeenth-century Jesuit occupation of St. Inigoes (18ST233), a high proportion when compared to contemporaneous archaeological sites in the Chesapeake. Moreover, higher than usual proportions of white-tailed deer and the presence of tenterhooks used to stretch hides also indicate a close connection between the site and the fur trade. The presence of a possible Native ossuary, located close to several late seventeenth- or eighteenth-century burials at St. Inigoes, shows that American Indians may have lived there shortly before or during the Jesuit occupation. ${ }^{36}$ While concrete evidence of connections between

"Priestly Plantations," 307-29 and Laura E. Masur, "Symbol or Presence?: Archaeology and the Materiality of Catholic Devotions," U.S. Catholic Historian 38, no. 2 (2020): 1-21, here 9-11 and 16-18, doi:10.1353/cht.2020.00o9.

35 Andrew White, Voyage to Maryland (1633): Relatio itineris in Marilandiam, ed. Barbara Lawatsch-Boomgaarden (Wauconda, IL: Bolchazy-Carducci Publishers, 1995), 37; Joseph Zwinge, "Our Fathers in the Colonization of Maryland," Woodstock Letters 36, no. 1 (1907): 78-92, here 84; "Cyprian Thorowgood," "Robert Clark," St. Mary's County Career Files: Dr. Lois Green Carr's Biographical Files of $17^{\text {th }}$ and $18^{\text {th }}$-Century Marylanders, no. 821, 4201. Maryland State Archive, http://speccol.msa.maryland.gov/carr/ (accessed January 14, 2021); Garry Wheeler Stone, "Manorial Maryland," Maryland Historical Magazine 82, no. 1 (1987): 3-36, 14-17; Scorza, "False Emissaries."

36 Terra cotta pipes comprise twelve to sixty-six percent of pipe assemblages studied by Susan Henry. Susan L. Henry, "Terra-Cotta Tobacco Pipes in 17th-Century Maryland and Virginia: A Preliminary Study," Historical Archaeology 13 (1979): 14-37; Al Luckenbach and Taft Kiser, "Seventeenth-Century Tobacco Pipe Manufacturing in the Chesapeake Region: A Preliminary Delineation of Makers and Their Styles," in Ceramics in America, ed. Robert Hunter (Hanover, NH: University Press of New Englands for the Chipstone Foundation, 2006); Masur, "Priestly Plantations," 139, 257; Christopher I. Sperling and Laura J. Galke, "Phase II Archaeological Investigations of 18ST233 and 18ST329 Aboard Webster Field Annex Naval Air Station, Patuxent River, St. Mary's County, Maryland," Report prepared for the 


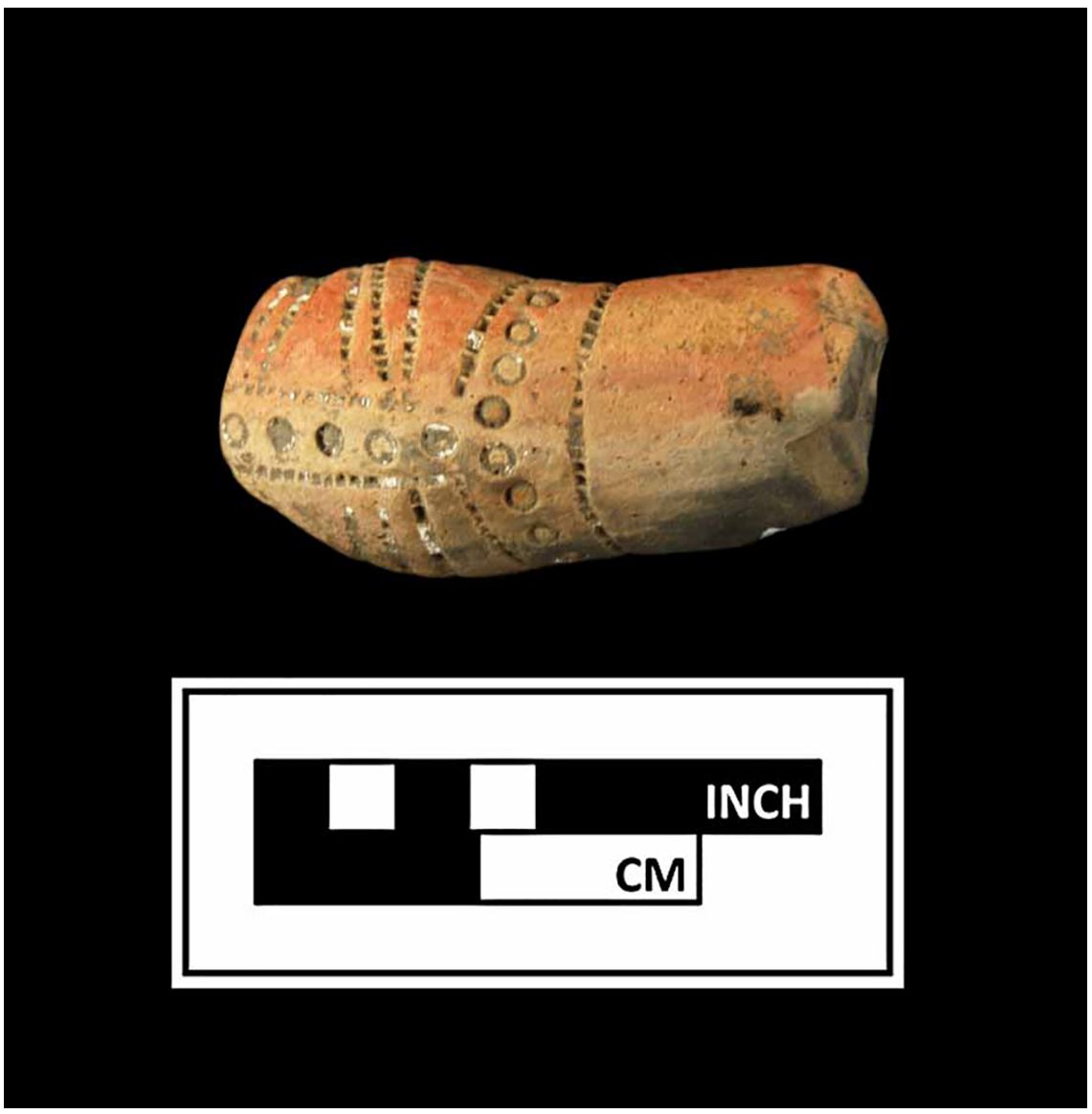

FIGURE 2 Red clay or terra cotta pipe fragment from St. Inigoes (18ST233)

IMAGE COURTESY OF THE COLONIAL ENCOUNTERS PROJECT WWW. COLONIALENCOUNTERS.ORG AND NAVAL AIR STATION PATUXENT RIVER'S WEBSTER FIELD ANNEX, NAVAL DISTRICT WASHINGTON

American Indians and seventeenth-century Jesuit plantations remains elusive, the limited available archaeological evidence hints at the effect of ongoing American Indian trade interactions at St. Inigoes.

After the mid-eighteenth century, there is little historical or archaeological evidence for ongoing Indian missions in the Middle Atlantic. Events surrounding the French and Indian War (1754-63), including the Paxton Boys' massacre of Susquehannocks at Conestoga Town in 1763, led to increased Native migration out of the region. While American Indians seemed to "disappear" from the historical record in Maryland, the ancestors of contemporary Piscataways remained in Maryland, intermarrying with people of European and African descent. In the late nineteenth and early twentieth centuries, a multiracial 
group known by the pejorative term "We Sorts" continued to self-identify with their Indian ancestry. ${ }^{37}$ These ancestors of some contemporary Piscataways remained connected to St. Thomas Manor (Portobacco) in Charles County, remembered as "We Sorts" by nineteenth- and twentieth-century Jesuits. ${ }^{38}$

Nonetheless, the Jesuits' missionary efforts after the mid-eighteenth century focused on the conversion of Protestants, as well as African American laborers enslaved on their own plantations. While the origins of Jesuit slaveholding in Maryland are poorly understood, their dependence on race-based slavery followed a system of indentured servitude that was prevalent in the seventeenth century. ${ }^{39}$ At least some enslaved people were bequeathed to the Jesuits. ${ }^{40}$ Fifteen individuals were enslaved at Newtown plantation in 1717: adults Will, Jack, Kitt, Pete, Mary, Teresa, Clare, and Peggy, and children Jack, Clemm, Tomm, James, Betty, Cath, and Susan. In 1743-44, the agricultural labor force at St. Inigoes consisted of nine enslaved Africans, supervised by at least one overseer. By 1765 , the Jesuits enslaved 192 persons across their seven Maryland plantations. George Hunter (1713-79), stationed at St. Thomas Manor in 1749, reflected on "Negroes" as "members of Jesus Christ, redeemed by his precious blood." Hunter called for a decreased focus on "temporals" - the profit-making aspect of the plantations - and a greater emphasis on "the progress of our Missions."41

Natural and Cultural Resources Branch, Environmental and Natural Resources Division, Department of Public Works, Naval Air Station Patuxent River, Jefferson Patterson Park and Museum Occasional Papers, no. 13 (St. Leonard, MD: Jefferson Patterson Park and Museum, Maryland Historic Trust, 2001).

37 Cissna, "Piscataway Indians," 2-3, 247-58. Late-nineteenth- and early twentieth-century anthropologists commonly observed that American Indian communities, especially in the eastern United States, were composed of mixed-race individuals. The members of many contemporary Indian tribes claim ancestry from European, African, and Indian ancestors. With reference to Virginia, see Danielle Moretti-Langholtz, "Other names I have been called': Political Resurgence among Virginia Indians in the Twentieth Century" (unpublished PhD diss., University of Oklahoma, 1998), 66-71.

38 Laurence J. Kelly, "Negro Missions in Maryland," Woodstock Letters 37, no. 2 (19o8): 239-44. "Bel Alton Maryland: 13oth Anniversary of the Laying of the Cornerstone of St. Ignatius' Church, St. Thomas' Manor," Woodstock Letters 57, no. 3 (1928): 558-6o.

39 John Wareing, Indentured Migration and the Servant Trade from London to America, 1618-1718 (Oxford: Oxford University Press, 2016). There is thus far no clear evidence of American Indian enslavement by the Maryland Jesuits.

40 For example, in 1729, James Carroll (1679-1729) bequeathed land and enslaved Africans to George Thorold (c.1671-1742) to hold in trust for the Society of Jesus. Maryland Province Archives (MPA), “James Carroll, 'An account of my negroes,' September 27, 1715," Georgetown Slavery Archive (GSA), https://slaveryarchive.georgetown.edu/items/show/135 (accessed January 14, 2021).

41 MPA, "Deed of gift between William Hunter, SJ and Thomas Jameson, January 30, 1717," GSA, http://slaveryarchive.georgetown.edu/items/show/403 (accessed January 14, 2021). Masur, 
The Jesuits' plantation churches became a focal point for the practice of Catholicism among enslaved Africans in southern Maryland. Over time, Jesuit influence led to widespread conversions among African Americans in Maryland. At 1768-69 St. Inigoes, fourteen of twenty enslaved Africans were listed in the St. Ignatius parish register. ${ }^{42}$ Baptismal records are a testament to the widespread practice of Catholicism by persons enslaved by the Jesuits at White Marsh. ${ }^{43}$ In 1831, "negroes" regularly walked several miles to St. Thomas Manor for confession and religious instruction. This was apparently a free choice, permitted because of Protestant enslavers' ambivalence about religious practice. ${ }^{44}$ By 1838 , Joseph Carberry (1776-1849) — stationed at St. Inigoes-observed that "all most all of the Blacks have imbraced [sic] the Catholic faith." 45

Archaeology, unfortunately, adds little to our understanding of enslaved life or religious practice on Jesuit plantations. Most archaeological projects have been surveys, aimed at identifying and preserving rather than investigating sites. More extensive projects, such as the multiple field investigations that have taken place at St. Inigoes or Newtown, have focused on identifying evidence of the Jesuit residential complexes rather than slave quarters. Archaeological evidence of early nineteenth-century slave quarters at St. Inigoes was most likely destroyed when the Navy constructed the airstrip at Webster Field in the early $1940{ }^{46}$ Although several recent projects have sought to identify slave quarters at Newtown, these survey projects have yet to provide conclusive evidence at the household scale, given the paucity of supporting maps or historical

"Priestly Plantations," 163-64. MPA, "'Charity to Negroes': Rev. George Hunter's reflections on the treatment of slaves, 1749," GSA, http://slaveryarchive.georgetown.edu/items/show/243 (accessed January 14, 2021).

42 Hughes, History of the Society of Jesus in North America, vol. 1, part 1:335-38. Beitzell, Jesuit Missions of St. Mary's County, 76.

43 For example, Maryland Province Collection, "Register of baptisms, White Marsh, 1818-1822 (transcription)," GSA, https://slaveryarchive.georgetown.edu/items/show/56 (accessed January 14, 2021).

44 Archivum Romanum Societatis Iesu, "Slavery at St. Thomas Manor: Fr. Grivel to Fr. Roothaan, 1831," GSA, http://slaveryarchive.georgetown.edu/items/show/292 (accessed January 14, 2021).

45 Tricia T. Pyne, "2.9 Historical Background," in Phase I Archaeological Investigations Aboard Webster Field Annex: NAS PAX, St. Mary's County, Maryland, Report Presented to Natural Resources Branch Environmental and Natural Resources Division Department of Public Works Naval Air Station Patuxent River, ed. Laura J. Galke and Alyssa L. Loney (St. Leonard, MD: Jefferson Patterson Park and Museum, Maryland Historic Trust, 2000), 44.

46 Masur, "Priestly Plantations," 108-9, 182. 
references. ${ }^{47}$ The only known slave quarter on a Maryland Jesuit plantation, adjacent to the manor house at St. Thomas, was expanded and moved from its original location, and has not been subject to thorough archaeological research. ${ }^{48}$ Future archaeological projects will provide a better understanding of how colonial and antebellum plantations-including slave quarters-contributed to the landscape of Jesuit missions in Maryland.

Archaeological evidence does, however, attest to the expansion of Black missions after emancipation. Roman Catholic devotional artifacts have been found at several nineteenth and twentieth-century African American archaeological sites, which radiate from the Society's former plantations and mission churches. For example, numerous medals, a cross, and a rosary fragment were recovered from two structures at Northampton Quarter in Prince George's County. One copper-alloy medal (Figure 3), inscribed with Chinese characters, depicts the Virgin Mary on the obverse and Saint Francis Xavier on the reverse. This medal was certainly intended for the Jesuits' Chinese missions but was ultimately brought to Maryland and ended up in the possession of African American tenant farmers. Lizzie (d.1934) and Robert Hawkins (b. c.1820), who lived at Northampton from at least 1870, baptized their daughter Rosa at Holy Family Catholic Church, established by the Jesuits as a mission to African American tenant farmers in Prince George's. A small lead Virgin Mary figurine and a holy family medal were also found by archaeologists excavating a quarter or tenant house at nearby Willow Grove plantation. African American tenant farmers from nearby Collington would walk to a Catholic Church in Bowie; this anecdote almost certainly refers to Sacred Heart Church, located on the Jesuits' expansive former plantation at White Marsh. ${ }^{49}$

47 Julia A. King, Christopher L. Coogan, and Scott M. Strickland, "Archaeological Investigations at Newtowne Neck State Park, Formerly Newtown Manor, Compton, Maryland," Report prepared for Maryland Department of Natural Resources, Maryland Heritage Areas Authority (St. Mary's City, MD: St. Mary's College of Maryland, 2017); Michael E. Ruane, "Former Jesuit Plantation May Hold Quarters of the Enslaved," Washington Post, November 9, 2020, https://www.washingtonpost.com/history/2020/11/og/enslaved-quarters-discoveredjesuit-plantation/ (accessed January 14, 2021). No known maps document the location of slave quarters at Newtown, and one document describes only " $\mathrm{y}^{\mathrm{e}}$ Quarter on $\mathrm{y}^{\mathrm{e}}$ bottom [?] $\mathrm{y}^{\mathrm{e}}$ sd neck," with no additional details on its location. MPA, "Deed of gift." It is very difficult to differentiate a slave quarter from the dwelling of an indentured servant or tenant farmer using archaeological evidence alone.

48 George W. McDaniel, "Slave Quarters, St. Ignatius Church," Maryland Historical Trust Inventory Form for State Historic Sites Survey CH-7A (Annapolis, MD, n.d.).

49 Kristin Marie Montaperto, "Public Archaeology and the Northampton Slave Quarters: Community Collaboration" (unpublished PhD diss., American University, 2012), 192-202. Matthew H. Gill et al., "Phase III Archaeological Data Recovery at the Willow Grove Site 


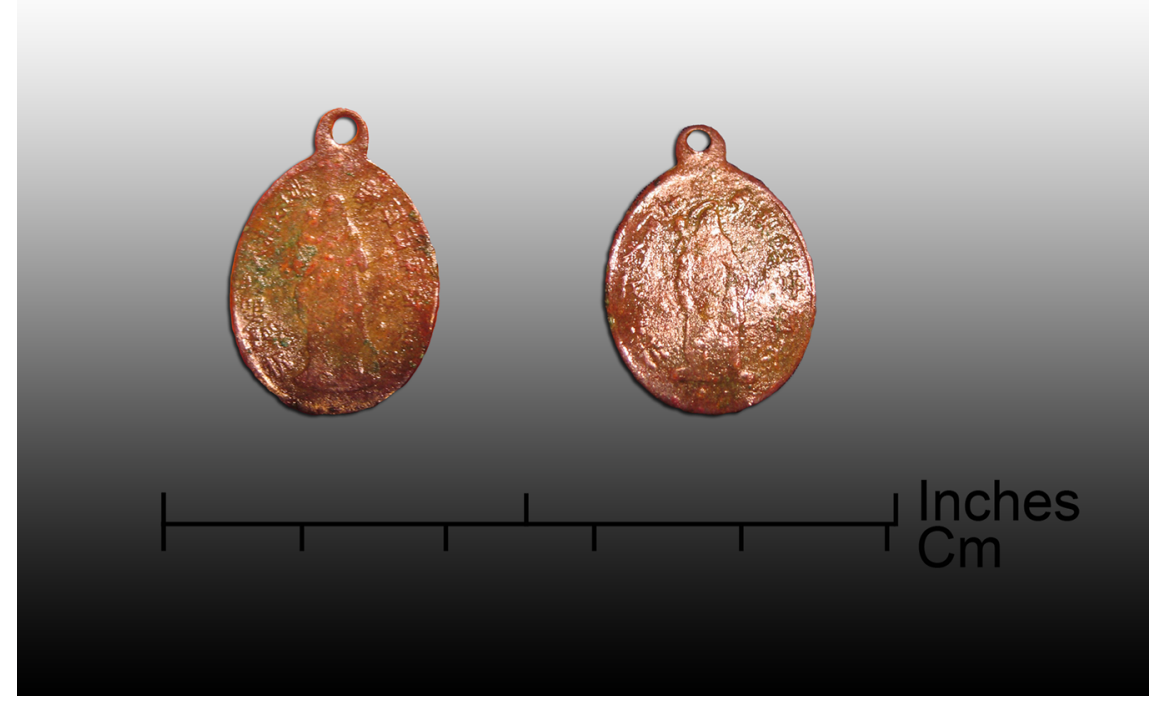

FIGURE 3 Copper alloy medal with Chinese characters from Northampton Quarter (18PR320A), depicting the Virgin Mary/Saint Francis Xavier

IMAGE BY KRISTIN M. MONTAPERTO, 2010

Efforts at spiritual conversion also extended to non-enslaved residents of the plantations. Based on the appearance of names on both tenancy and sacramental records at St. Inigoes, it is clear that Jesuit planters either recruited Catholics or frequently converted their tenant farmers. In one 1759 example, Arnold Livers (1705-67) instructed two tenants-John Drury (dates unknown) and William Spalding (dates unknown) - in the Spiritual Exercises. He also lent religious texts to Molly Herbert (dates unknown) and Mary Fenwick (dates unknown), probably the members of tenant families based on their surnames..$^{50}$ A French Miraculous Medal (Figure 4) from the nineteenth-century tenancy at Blossom Point Farm in Charles County provides material evidence of evangelical practice. ${ }^{51}$ Moreover, in a 1788 pamphlet, Rev. Patrick Smith (dates unknown) criticized the then ex-Jesuits for inviting Catholics to "flock around the skirts of the overgrown plantations of the clergy." To Smith, movement west was in the best interests of the Catholic Church as well as Catholic farmers, who would have greater opportunity to advance their economic interests..$^{52}$

(18PR510), Prince George's County, Maryland," Report Prepared for Mid-Atlantic Companies, Rockville MD (Laurel, MD: Greenhorne \& O’Mara, 2006), 37. Masur, "Priestly Plantations," 343-46.

50 Masur, "Priestly Plantations," $25^{-}{ }^{-6}$.

$51 \quad$ Rivers Cofield, "Religious Artifacts."

52 Patrick Smith, The Present State of the Catholic Mission, Conducted by the Ex-Jesuits in NorthAmerica (Dublin: Printed by P. Byrne, no. 108, Grafton-Street, 1788), 27. Smith argued that the 


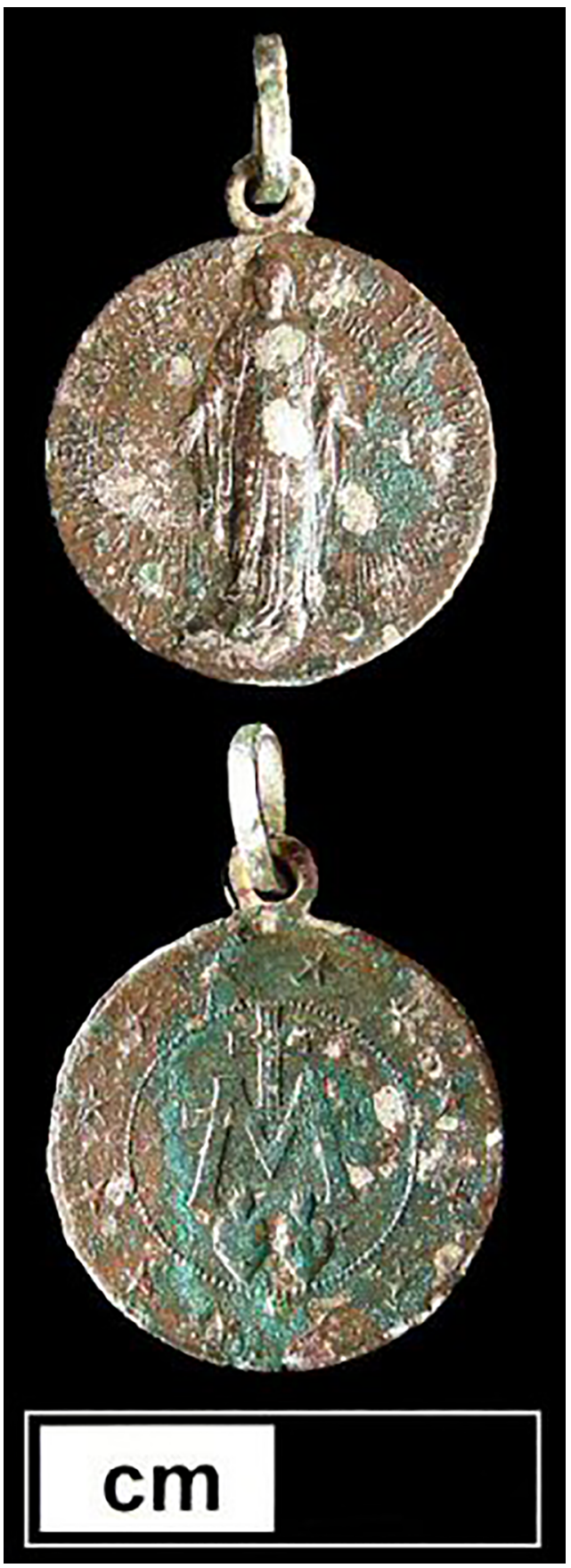

FIGURE 4 Copper alloy miraculous medal from the Jesuit tenant house at Blossom Point (18CH216)

IMAGE COURTESY OF U.S. ARMY GARRISON ADELPHI LABORATORY CENTER 
During the suppression, there appears to have been increasing problems with ex-Jesuits - who, in Maryland, operated much as they had before 1773about how to balance the mission's temporal and spiritual goals. Plantations were mismanaged, and as Peter Kenney (1779-1841) observed in 1819, priests had become preoccupied with their temporal role as planters, negatively impacting their spiritual responsibilities as missionaries. Ultimately, the Maryland Jesuits' decision to sell 272 enslaved Africans en masse to Louisiana in 1838 not only provided financial support for the indebted plantations, Georgetown University, and the Catholic Church in the United States, but allowed Jesuits to shift their focus away from their plantations as missions to enslaved Africans and tenant farmers. ${ }^{53} \mathrm{Just}$ as economic dependence on slavery led missionaries to evangelize enslaved African Americans, the decline of plantation profitability in the nineteenth century influenced the Jesuits' choice to quite literally sell the human bodies of this mission "down the river" to Louisiana. The conflict between the temporal goals of the plantation as a capitalist enterprise and the spiritual goals of the plantation as a mission was central both to their financial failure, and the ensuing slave sale.

While missions to African Americans and other communities surrounding the former plantations continued - as evidenced by the artifacts discussed above and by numerous accounts in the Woodstock Letters - the focus of Jesuit ministry shifted to university education and outreach to the influx of European immigrants that flooded into American cities during the second half of the nineteenth century. Indeed, Thomas Murphy frames discussions surrounding the slave sale as a choice between "the slave and the immigrant." Ministry in cities-Philadelphia, Washington DC, New York, and Boston-was deemed more important than the continued operation of their economically failing plantations-as-missions. ${ }^{54}$

\section{Conclusion}

Archaeological evidence of missions in Maryland, however fragmented, leads to a narrative of the Maryland mission that is at odds with histories written

ex-Jesuits' only goal was to increase the values of their land and await the restoration of the Society.

53 Masur, "Priestly Plantations," 229-43; Thomas J Morrissey, Peter Kenney, SJ, 1779-1841: The Restoration of the Jesuits in Ireland, England, Sicily, and North America (Washington, DC: Catholic University of America Press, 2014), 150-67; Rothman, "Georgetown University."

54 E.g., John Scully, "Mission Work around St. Inigo's, MD: A Letter from Father John Scully, S. J.," Woodstock Letters 33, no. 1 (1904): 35-46; Murphy, Jesuit Slaveholding in Maryland. 
during the nineteenth and twentieth centuries. Furthermore, archaeology demonstrates the importance of critically reflecting on the effect of available historical evidence, including a historiographic focus on either mission or plantation, within the written history of the Jesuits in the Americas. In the Americas and particularly in Maryland, the strategy of Jesuit accommodation led to a system of missions characterized by flexibility and mobility. As a result, archaeological sites within Indigenous villages, on tenant farms, and within slave quarters have not been consistently connected with Jesuit missions. Careful analysis of both historical and archaeological evidence can show connections between known Jesuit sites like plantations, universities, or churches, and obscure or ephemeral residential sites.

Investment in plantations and African enslavement was an adaptive mechanism to the economic needs of Jesuit missions throughout the Americas. In Maryland, however, privately (rather than corporately) owning plantations enabled missionaries to navigate often tense political relationships with colonial governments. These challenges also led missionaries to maintain silence about ongoing missionary outreach to Piscataways, Susquehannocks, and possibly other Indigenous groups. Indian missions can also be connected with predominantly Black plantation landscapes. As a result, it is impossible to separate Jesuit missions and plantations, either in terms of religious/ economic objectives or physical space. Mission as an overarching goal transcended categories of race or ethnicity. Moreover, the Maryland mission as a spiritual endeavor became entangled with a variety of economic relationships, whether through trade, enslavement, or tenant farming. It is clear that people of American Indian, African, and European descent have been connected with Jesuit plantations and missions throughout their history. The legacy of missions associated with plantations persists today, for example, among Piscataways who attend St. Ignatius Church (St. Thomas Manor) and African American parishioners of St. Peter Claver Church, an offshoot of the original mission at St. Inigoes. Although Jesuit missionaries in the nineteenth century chose to minister to urban white Catholic immigrant populations, their influence on spiritual belief and community formation among rural nonwhite Catholics in Maryland was nonetheless profound. 